\title{
Labyrintem českých novověkých edic
}

Dne 20. března 2018 uspořádal Moravský zemský archiv ve svých brněnských prostorách odborný workshop, zaměřený na problematiku edičního zpřístupňování raně novověkých písemných památek. Původní představa o uzavřeném kruhu menšího počtu aktivních editorů, kteří by si vyměňovali zkušenosti ze své práce a diskutovali o způsobech řešení metodických problémů, se poněkud vymknula a na místě se nakonec sešlo několik desítek zájemců, čímž se z workshopu fakticky stala malá konference, jejíž páteřní program tvořila vystoupení renomovaných archivářů a historiků z akademického i archivního prostředí. Velmi důležitou součástí programu byly ovšem i diskuze, a to jak ,programové“, navazující na jednotlivé bloky př́spěvků, tak neformální, odehrávající se v pověstných „kuloárech“.

Program zahájilo (po uvítacím proslovu ředitele archivu, dr. Ladislava Macka) vystoupení prof. Ivany Ebelové z Katedry pomocných věd historických a archivního studia Filozofické fakulty Univerzity Karlovy, nesoucí název Otázky vydávání raně novověkých písemných pramenů na príkladu edičních projektů $v$ České republice a v sousedních zemích (Německo, Polsko). Její příspěvek, jehož komparativní rozměr naznačoval již samotný název, se zaměřil především na praktické problémy ediční činnosti, přičemž v neposlední řadě upozornil na otázku financování edičních prací, bez jehož uspokojivého zajištění je jakákoliv činnost na tomto poli jen stěží myslitelná. Vystupující také komentovala problematickou využitelnost starších edicí (zejména z 19. století), což vede k potřebě vydat některé památky znovu, v moderním kritickém hávu.

Filologickým otázkám se věnoval prof. Karel Kučera z Ústavu Českého národního korpusu Filozofické fakulty Univerzity Karlovy, jenž se zaměřil na České zápisy v městských knihách: jazykové problémy. Upozornil, že právě v období raného novověku došlo k bouřlivému vývoji jazyka a že velkým metodickým problémem ediční práce je skutečnost, že i v rámci jednotlivých památek, ba i v rámci textů psaných jediným autorem se lze setkat s kolísavým hláskoslovím, syntaxí i slovní zásobou, kdy jeden a týž termín mění svůj význam, a zdůraznil, že i tato diverzita by měla být v rámci ediční práce nějakým způsobem reflektována. Stručně pak zmínil některé online dostupné lexikální databáze.

Druhou, předobědovou sekci tvořil vzhledem $\mathrm{k}$ absenci jedné z přednášejících pouze jediný příspěvek. Přednesl ho dr. Tomáš Sterneck z Centra raně novověkých studií Historického ústavu Akademie věd ČR. Ten své bohaté zkušenosti se zpř́istupňováním materiálů z někdejšího rožmberského rodového archivu shrnul do proslovu s názvem Transkripce versus transliterace. Ke zpř́stupňování českojazyčných textů v rámci edičního projektu 
Historica Třebon̆ 1526-1547. Představil samotnou sbírku Historica a stav jejího edičního zpracování, následně se věnoval především transliteraci jako jednomu ze způsobů, jímž je možno historický text uživateli zpř́stupnit. Upozornil, že ani tato cesta není prosta metodických úskalí (nejednoznačnost slovních rozhraní, více grafémů pro jednu hlásku, velikost počátečních písmen), a vyjádřil přesvědčení, že transliterace českých textů od 16. století směrem k současnosti je nutno považovat za lapsus a že tento způsob zpracování historického textu ve finále uživateli práci spíše znesnadňuje, než zjednodušuje. Naproti tomu ve vztahu k primárně použité transkripci může být transliterace nejednoznačných pasáží velmi užitečným doplňkem.

Odpolední program zahájil Zdeněk Vybíral z Husitského muzea v Táboře. Jeho vystoupení Edice pamětí urozeného válečníka navazovalo na jeho nedávno vydanou edici zápisků českého rytíře Pavla Kůrky z Korkyně a jeho snahou bylo upozornit na dva druhy problémů: první se týkaly samotné ediční práce, druhé pak interpretace editovaného textu. Mezi prvními upozornil zejména na omezenou př́istupnost archiválií, nacházejících se v soukromých sbírkách (konkrétně Korkovy paměti jsou uchovávány v rodinném archivu Lobkoviců), jakož i na nutnost dosažení příslušných souhlasů s jejich publikačním zpřístupněním. Velkým problémem transkripce může být také předchozí identifikace osobních a místních jmen. Analýza textu by pak měla směřovat k co nejpodrobnějšímu poznání osobnosti autora, přičemž zásadní je otázka motivace vzniku příslušné písemné památky.

Z hlediska právněhistorického měl pochopitelně zcela zásadní význam př́ispěvek dr. Jany Janišové z Katedry teorie práva a právních dějin Právnické fakulty Univerzity Palackého v Olomouci Edični zpř́stupňováni právněhistorických pramenů (moravské zemské právo). V jeho úvodu zhodnotila starší edice, přičemž konstatovala, že moravské zemské právo je na tom z hlediska ediční dostupnosti textů paradoxně lépe než české. Dále upozornila na skutečnost, že pro právněhistorické texty je charakteristická dobrá čitelnost (jejich původci byli zpravidla školení a praxí prověření písaři) a stejně tak i množství ustálených slovních spojení. Hlavním problémem se tak stává spíše interpretace textu, jehož editování prakticky není možné bez důkladného porozumění jeho juristické náplni. Zmínila též konkrétní problémy spojené s některými archiváliemi a nakonec vyslovila několik tezí ohledně členění textu. To je podle jejího názoru u právních textů naprosto klíčové, především kvůli potřebě jednoznačnosti jejich dalšího komentování. Proto je podle jejího názoru zcela přijatelné, pokud editor sáhne k podrobnějšímu členění, než jaké je obsaženo v originálním historickém textu.

Dále pohovořil zástupce pořádající instituce, dr. Pavel Holub, působící ve Státním okresním archivu v Pelhřimově (který je pobočkou MZA). Jeho vystoupení neslo název Tři edice - tři př́stupy. Specifika př́stupu k ediční činnosti na př́kladu písemností městské a stavovské provenience, ve skutečnosti se ale dominantně věnovalo pouze dvěma edicím pramenů městské provenience, totiž Pamětní knihy města Pacova z let 1473-1712 a Knihy o koupi pelhřimovského statku, vzniklé ve druhé polovině 16. století. Na uvedených př́kladech bylo celkem přesvědčivě demonstrováno, že odlišnosti jednotlivých rukopisů skutečně mohou racionálně zdůvodnit individualizovaný přístup k jejich edičnímu zpř́ístupnění. Z metodického hlediska vzbudily pozornost výklad o hledání systematiky při studiu neobvykle uspořádané knihy pacovské, jakož i úvahy o tom, zda mají být písařské zkratky rozepisovány v hranatých závorkách, což vyvolalo následnou obšírnou debatu o využitelnosti těchto závorek a o prípustné míře zásahů editora do původního textu. 
Také poslední blok se nesl v duchu představení konkrétních edičních projektů. Jako první tu vystoupili dr. Marek Ďurčanský z Ústavu dějin Univerzity Karlovy a archivu Univerzity Karlovy a mgr. Roman Kolek ze Státního oblastního archivu v Praze, resp. Státního okresního archivu Praha - východ. Výsledkem jejich společného úsilí se nedávno stala Edice čelakovického radního manuálu Pavla Ježdika (1639-1654), přičemž jejich vystoupení neslo výmluvný podtitul Představy a realita. Zmíněná památka prritom co do názvu poněkud „,klame tělem“, nebot' se ve skutečnosti nejedná o klasický manuál, ale o obsahově poměrně pestrou úřední knihu. Poslední řečník, dr. Tomáš Velička z Katedry historie Filozofické fakulty Univerzity J. E. Purkyně v Ústí nad Labem, věnoval svůj obecně pojmenovaný prŕspěvek Hradní regestár. Smysl publikování písemných pramenů se vztahem $k$ hradưm a jejich panstvím (14.-17. století) svému diplomatáři k dějinám hradu Kašperka. Ten má primárně podobu regestáře, avšak s tím, že některé písemnosti jsou v něm editovány in extenzo. $Z$ tohoto pohledu reprezentoval jeho příspěvek v kontextu ostatních značně atypický metodický přístup, což mu ovšem neubíralo na zajímavosti. Vyzdvihnout je přitom třeba jeho zamyšlení nad nastavením kritérií výběru editovaných písemností. Závěrečné hodnotící resumé celého workshopu pronesla doc. Ludmila Sulitková, rovněž zastupující Katedru historie Filozofické fakulty Univerzity J. E. Purkyně v Ústí nad Labem.

Ačkoliv př́mo právněhistoricky byl zaměřen jediný ze zazněvších př́ispěvků, nutno zdůraznit, že workshop byl i z pohledu právní historie nesmírně inspirativní. Nezazněl na něm příspěvek, který by nevedl k hlubokému zamyšlení. Zpřístupňování historických právních památek je dozajista významnou součástí rozvíjení a stejně tak do jisté míry i popularizace právních dějin. Juristická výbava je při zpracování obsahově specifických historickoprávních pramenů nanejvýš žádoucí, nebot' bez ní lze těžko aspirovat na skutečně důkladné porozumění textu i širšímu kontextu. Zároveň ale platí, že i u těchto památek by měla ediční práce naplňovat standardy uznávané v oboru historie obecně. Jedině tak si bude moci právní historie jakožto disciplína stojící na pomezí věd právních a historických udržet dostatečný kredit ve vztahu k reprezentantům posledně jmenovaných.

Na závěr budiž dodáno, že celkové vyznění workshopu bylo do jisté míry liberální - ani historici nejsou schopni nabídnout jednotnou, univerzálně použitelnou ediční metodiku. Jako podtón všech př́spěvků se ale neslo zdůraznění dvou požadavků, jichž by se měly moderní edice držet: prvním z nich je užití takových transkripčních postupů, které edici pokud možno co nejvíce zpř́ístupní uživateli, druhým pak souběžné využití takových postupů, jež v př́ipadě potřeby umožní co nejdokonalejší rekonstrukci původní podoby textu se všemi jeho specifiky.

doi: 10.14712/2464689X.2018.35

Marek Starý 